\title{
Early Miocene paleomagnetic results from the Ninohe area, NE Japan: Implications for arc rotation and intra-arc differential rotations
}

\author{
Hiroyuki Hoshi* and Takashi Matsubara** \\ Institute of Geology and Paleontology, Graduate School of Science, Tohoku University, Aoba-yama, Sendai 980-77, Japan
}

(Received February 21, 1997; Revised October 14, 1997; Accepted October 14, 1997)

\begin{abstract}
We have carried out a paleomagnetic study on well-dated Early Miocene volcanic rocks from the Ninohe area in northern NE Japan. Dacitic welded tuffs ranging from 24 to 21 Ma possess westerly paleomagnetic directions with normal polarity (formation-mean: $D / I=294.5^{\circ} / 44.2^{\circ}$ with $\alpha_{95}=8.3^{\circ}, 8$ sites), while the andesite flows formed at $17 \mathrm{Ma}$ exhibit southerly directions with reversed polarity $\left(D / I=186.6^{\circ} /-61.9^{\circ}, 2\right.$ sites $)$. A positive conglomerate test assures the stability of high-temperature components of remanent magnetization. Our results demonstrate that northern NE Japan rotated counter-clockwise through more than $60^{\circ}$ between 21 and 17 Ma, most likely in association with the opening of the Japan Sea. The rotation of northern NE Japan thus preceded the about $15 \mathrm{Ma}$ rapid clockwise rotation of SW Japan, and was synchronous with the possible pre-16 Ma southward translation of it. In comparison with published data, we further suggest that intra-arc block rotations occurred in the back-arc region of NE Japan during and after the arc rotation.
\end{abstract}

\section{Introduction}

It is widely accepted that NE and SW Japan rotated counter-clockwise and clockwise, respectively, in late Cenozoic time in association with the opening of the Japan Sea. The rotational process of SW Japan is well established based on the paleomagnetic database that has been growing since the 1980's (Otofuji, 1996, and references therein); it seems to have rotated through more than $40^{\circ}$ at about $15 \mathrm{Ma}$. The rotational process of NE Japan also has been discussed by many researchers based on late Mesozoic to Cenozoic paleomagnetic data (Otofuji et al., 1985, 1994; Celaya and McCabe, 1987; Moreau et al., 1987; Nishitani and Tanoue, 1987; Tosha and Hamano, 1988; Fujiwara, 1992). Recently, Otofuji et al. (1994) have emphasized that northern NE Japan rotated counter-clockwise through more than $45^{\circ}$ at about $15 \mathrm{Ma}$ as a "single rigid block," accompanying the contemporaneous rapid clockwise rotation of SW Japan. However, we have known that some of 15-16 Ma geologic formations in NE Japan possess no deflected remanent magnetization directions (Tosha and Hamano, 1988; Yamazaki, 1989; Tanaka et al., 1991; Hoshi et al., 1992; Hayashida, 1994; Hoshi and Takahashi, 1997). This suggests either that, as first pointed out by Yamazaki (1989), the coherent rotation of NE Japan had already ended by 15-16 $\mathrm{Ma}$, or that, as illustrated by Jolivet et al. (1995), intra-arc deformation with relative block rotations took place in Early to Middle Miocene time. To resolve this issue, we need to further accumulate time-averaged, reliable paleomagnetic

\footnotetext{
* Now at: Department of Environmental Earth Sciences, Aichi University of Education, Kariya 448, Japan.

**Now at: Museum of Nature and Human Activities, Hyogo, Sanda 669-13, Japan.
}

Copy right $($ The Society of Geomagnetism and Earth, Planetary and Space Sciences (SGEPSS); The Seismological Society of Japan; The Volcanological Society of Japan; The Geodetic Society of Japan; The Japanese Society for Planetary Sciences. directional data from individual areas.

This paper presents new paleomagnetic results from Early Miocene volcanic rocks in the Ninohe area, located on the fore-arc side of northern NE Japan (Fig. 1). Recently, Hayashida (1994) has reported preliminary paleomagnetic results from early Middle Miocene sedimentary rocks of this area. Thus our paleomagnetic approach has been focused on terrestrial volcanic rocks older than $16 \mathrm{Ma}$. Our newlyobtained data indicate that the area underwent counterclockwise rotation of more than $60^{\circ}$ between 21 and $17 \mathrm{Ma}$. Taken into consideration with published paleomagnetic data from other areas, we will discuss the amount and timing of counter-clockwise rotation of NE Japan and Early to Middle Miocene intra-arc differential rotations.

\section{Geology, Sampling and Tilt Correction}

Figures 1 and 2 show a simplified geological map and the generalized stratigraphy of the Lower to Middle Miocene sequence of the Ninohe area, respectively. The Lower to Middle Miocene strata are divided into the following four formations in ascending order; the Nisatai Dacite, Yotsuyaku Formation, Kadonosawa Formation, and Suenomatsuyama Formation. The Yotsuyaku Formation intercalates andesitic volcanic rocks, called the Keiseitoge Andesite, within the middle part. For details of lithostratigraphy and paleontology, refer to Matsubara (1995) and references therein. We carried out paleomagnetic sampling mainly from the Nisatai Dacite, Keiseitoge Andesite, and andesite dikes intruding the lower Yotsuyaku Formation.

The Nisatai Dacite consists mainly of biotite-rich dacitic welded tuffs. A eutaxitic texture can easily be recognized in each outcrop. A K-Ar biotite age of $21.0 \pm 0.3 \mathrm{Ma}$ and two fission-track zircon ages of $21.8 \pm 1.4 \mathrm{Ma}$ and $23.9 \pm 1.4 \mathrm{Ma}$ have been reported from the welded tuffs (Tagami et al., 1995). 


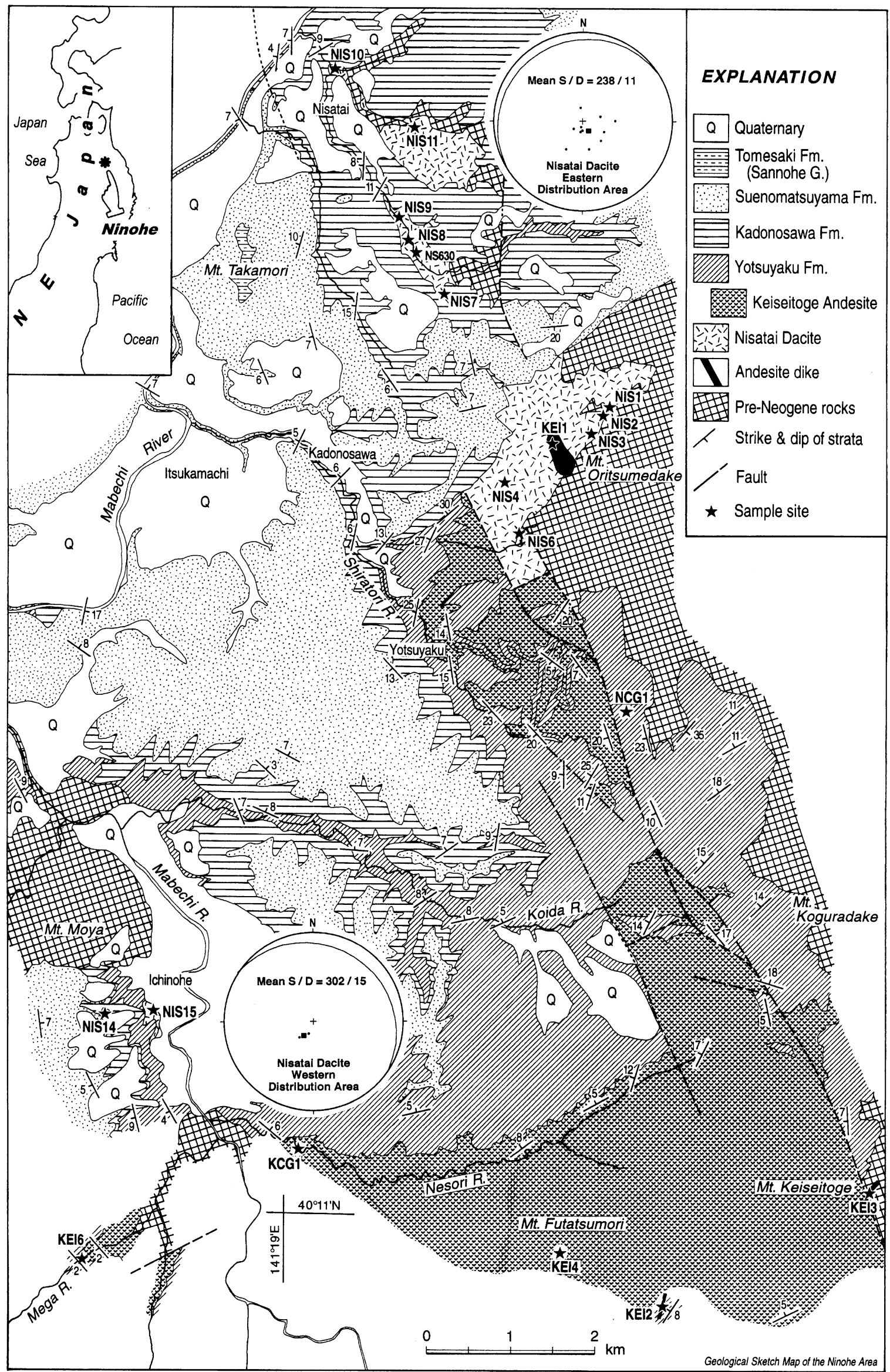

Fig. 1. Simplified geological map of the Ninohe area. Paleomagnetic sampling sites are shown by stars. Site NS630 studied by Otofuji et al. (1985) is also plotted. Lower-hemisphere equal-area projections display poles to local foliation of eutaxitic texture in outcrops (dots) and poles to mean foliation (squares). 


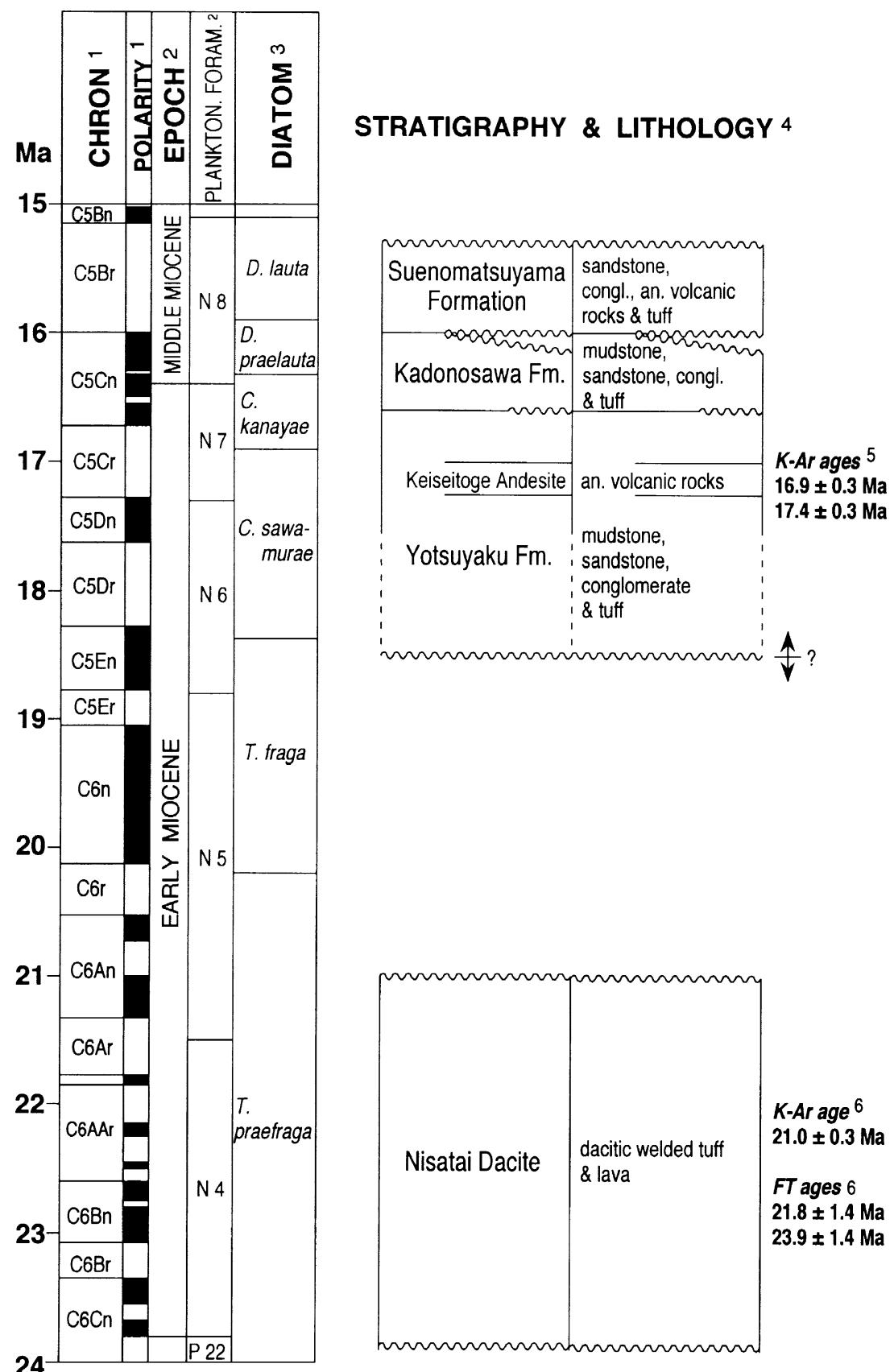

Fig. 2. Generalized stratigraphy of Lower to Middle Miocene strata in the Ninohe area. 1: Cande and Kent (1995). 2: Blow (1969), Berggren et al. (1995). 3: Barron and Gladenkov (1995). 4: Samata (1976), Koizumi (1986), Irizuki and Matsubara (1994). 5: Ishizuka and Uto (1995). 6: Tagami et al. (1995).

The Keiseitoge Andesite is composed mainly of andesitic volcaniclastic deposits with minor aa- and block-type lava flows. The andesitic volcanics commonly contain large $(\sim 3$ $\mathrm{mm}$ ) hornblende phenocrysts, which is a characteristic of the Keiseitoge Andesite. Ishizuka and Uto (1995) have recently reported K-Ar ages of $17.4 \pm 0.3 \mathrm{Ma}$ and $16.9 \pm 0.3$ Ma from a hyaloclastite of this andesite.

A few non-porphyritic andesite dikes have intruded the lower Yotsuyaku Formation (horizons below the Keiseitoge Andesite), Nisatai Dacite, and basement rocks (Fig. 1). These dikes closely resemble each other in lithofacies, and the facies differs markedly from that of the Keiseitoge Andesite, implying that the dikes were not the feeders of the Keiseitoge Andesite. In addition, we could not find the non- porphyritic andesite dikes in the Keiseitoge Andesite and the upper strata. These observations suggest that the intrusion occurred between $21 \mathrm{Ma}$ (Nisatai Dacite) and $17 \mathrm{Ma}$ (Keiseitoge Andesite).

Samples for paleomagnetic measurement were taken from dacitic welded tuffs of the Nisatai Dacite (12 sites), andesite lava flows of the Keiseitoge Andesite (2 sites), non-porphyritic andesite dikes ( 3 sites), and conglomerate beds within the Yotsuyaku Formation (2 sites). All sites are displayed in Fig. 1, including site NS630 studied by Otofuji et al. (1985). At each site, five or more core samples were taken with a portable drill fitted with a l" coring bit, yielding more than 140 core samples from 19 sites. Samples were oriented with a magnetic compass. One to five specimens, 

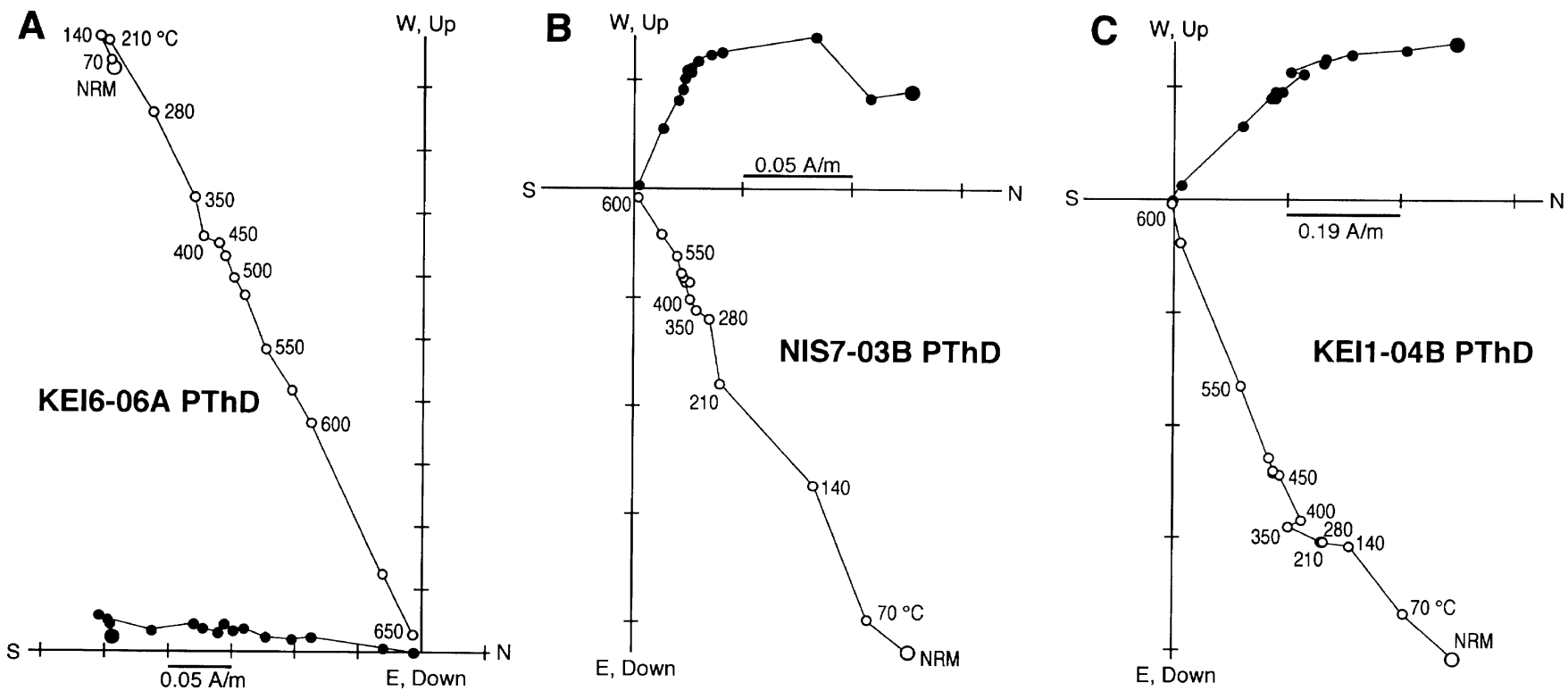

Fig. 3. Orthogonal demagnetization diagrams of representative specimens. A: Keiseitoge Andesite. B: Nisatai Dacite. C: Non-porphyritic andesite dikes. Solid and open circles are projections in the geographic coordinates onto the horizontal and vertical N-S plane, respectively.

$22 \mathrm{~mm}$ long, were cut from each core sample.

The Nisatai Dacite is exposed in two areas; east and west limbs of a gentle syncline plunging northwest (Fig. 1). A planiform foliation of eutaxitic texture was identified and sampled at each outcrop of welded tuffs. Eutaxitic texture, however, seems not to represent the paleohorizontal because this may have been influenced by a primary slope. To reduce the errors in tilt correction caused by this uncertainty, we calculated a mean dip and strike value for each distribution area (Fig. 1) and utilized the calculated data for tilt correction. For the Keiseitoge Andesite, bedding planes of intercalated fine-grained sedimentary layers were measured for tilt correction. We do not perform tilt correction for nonporphyritic andesite dikes due to a paucity of structural information.

\section{Paleomagnetism}

\subsection{Laboratory procedures and magnetic behavior}

Measurement of remanent magnetization was carried out using a Schonstedt SSM-2A spinner magnetometer at Tohoku University. As a pilot study, one specimen per site was chosen for the progressive thermal demagnetization (PThD) analysis. In this study alternating field demagnetization was not applied as in our experience thermal demagnetization is in general more appropriate to effectively demagnetize high-coercivity magnetization in felsic to intermediate volcanic materials. PThD was performed in more than 12 steps up to $650^{\circ} \mathrm{C}$. Specimens were heated in air using a noninductively wound electric furnace. Because pilot specimens of sites NIS1, NIS2, NIS3, NIS4, and NIS14 were broken during PThD, experiments on these sites were stopped at this point. After the pilot study, remaining specimens were also subjected to PThD. Results for each specimen were plotted on an orthogonal vector diagram (Zijderveld, 1967). For all specimens demagnetized at three or more steps, principal component analysis (Kirschvink, 1980) was done to determine least-squares best fit of the characteristic component of magnetization as determined from linear decay toward the origin on orthogonal vector diagrams.

The Nisatai Dacite and non-porphyritic andesite dikes are characterized by two distinct components (B and C in Fig. 3). The low-temperature component (LTC) of most samples had a north-seeking in-situ direction with normal polarity, and was unblocked by $350^{\circ} \mathrm{C}$. The high-temperature component (HTC) was demagnetized by $600^{\circ} \mathrm{C}$, suggesting that the component primarily resides in magnetite. On the other hand, all samples of the Keiseitoge Andesite displayed a single magnetic component with unblocking temperature of $210-650^{\circ} \mathrm{C}$ (Fig. 3(A)). Small viscous remanent magnetization (VRM) components were removed during the first few steps. Both magnetite and hematite probably carry the stable component.

\subsection{Magnetic components}

Table 1 lists the site-mean paleomagnetic directions. Figure 4 shows the equal-area projections of tilt-corrected site-mean directions of HTC.

Dacitic welded tuffs from 7 sites of the Nisatai Dacite provided reliable paleomagnetic records. All sites had normal polarity and northwesterly to westerly directions. Otofuji $e t$ al. (1985) also reported a westerly deflected site-mean direction from the Nisatai Dacite (site NS630: Fig. 1). Values of the radius of the $95 \%$ confidence circle $\left(\alpha_{95}\right.$; Fisher, 1953) were less than $8^{\circ}$ for every site-mean, indicating homogeneous magnetization. The formation-mean direction, $D / I=294.5^{\circ} / 44.2^{\circ}$ with $\alpha_{95}=8.3^{\circ}$, was derived from the tiltcorrected site-means of 8 sites (including NS630). The paleomagnetic north pole was at $34.7^{\circ} \mathrm{N}, 58.5^{\circ} \mathrm{E}$ with $A_{95}=$ $8.4^{\circ}$.

Two reliable site-mean directions with reversed polarity were obtained from andesite lava flows of the Keiseitoge Andesite. These site-mean directions were taken from distinct, separate lava flows (Fig. 1). The $\alpha_{95}$ values were less than $8^{\circ}$ for the site-means. The site-mean directions coincide 
Table 1. Paleomagnetic data from the Ninohe area.

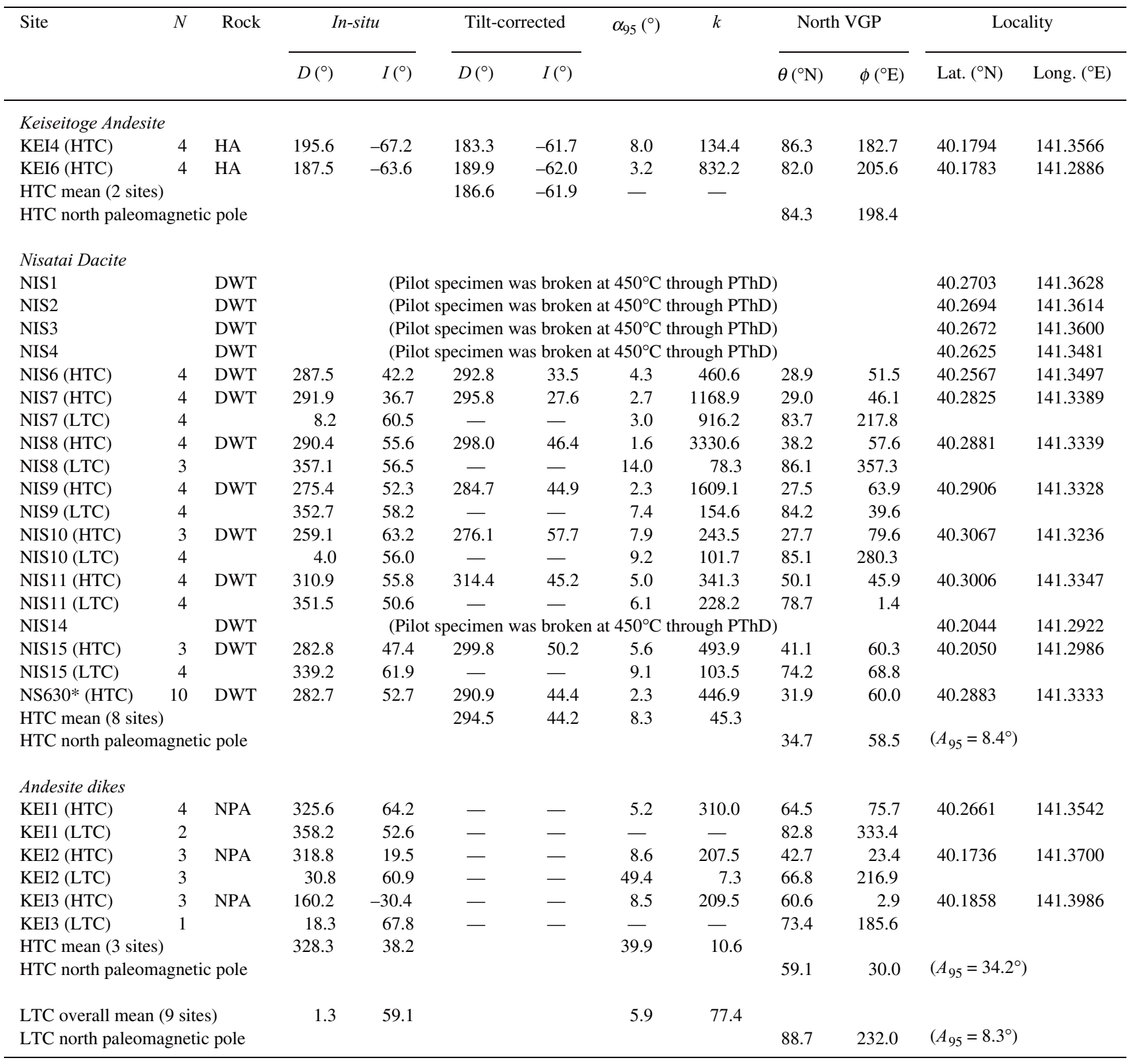

HTC, LTC = high-temperature component and low-temperature component, respectively. $N=$ number of samples used for calculating the site-mean direction. Rock: DWT = dacitic welded tuff, $\mathrm{HA}=$ hornblende andesite, $\mathrm{NPA}=$ non-porphyritic andesite. $D, I=$ declination and inclination. $\alpha_{95}=$ radius of cone of $95 \%$ confidence. $k=$ precision parameter. $\theta, \phi=$ latitude and longitude of virtual geomagnetic pole (VGP), respectively. Data denoted by asterisk are from Otofuji et al. (1985).

well with each other after tilt correction. The formationmean direction calculated from the tilt-corrected site-means was $D / I=186.6^{\circ} /-61.9^{\circ}$. Site-mean virtual geomagnetic poles (VGPs) yielded a paleomagnetic north pole of $84.3^{\circ} \mathrm{N}$, $198.4^{\circ} \mathrm{E}$.

Three in-situ site-mean directions were obtained from non-porphyritic andesite dikes with both normal and reversed polarities. All site-means had a tendency to deflect counter-clockwise from the north-south in spite of no tilt correction. Inclination values were diverse $\left(19.5-64.2^{\circ}\right)$. After inverting the reversed polarity site-mean direction to the normal polarity one, the mean paleomagnetic direction for these dikes became $D / I=328.3^{\circ} / 38.2^{\circ}$ with $\alpha_{95}=39.9^{\circ}$. The paleomagnetic north pole was observed at $59.1^{\circ} \mathrm{N}$, $30.0^{\circ} \mathrm{E}$ with $A_{95}=34.2^{\circ}$. These results from the dikes are not considered in the following tectonic discussion due to their fairly large uncertainty.

Low-temperature components (LTCs) were revealed from 6 sites of the Nisatai Dacite and 3 sites of non-porphyritic andesite dikes. Each component was estimated using at least four endpoints with maximum angular deviation (MAD) smaller than $10^{\circ}$. The in-situ overall mean was $D / I=1.3^{\circ} \%$ $59.1^{\circ}$ with $\alpha_{95}=5.9^{\circ}$, which is statistically indistinguishable from the geocentric axial dipole field direction $\left(I=59.5^{\circ}\right)$ expected at the latitude of the study area. Upon structural correction at each site, the mean direction shifted slightly upward $\left(D / I=358.1^{\circ} / 52.4^{\circ}\right.$ with $\left.\alpha_{95}=7.4^{\circ}\right)$. Thus it is most likely that the LTCs are secondary overprints of VRM 


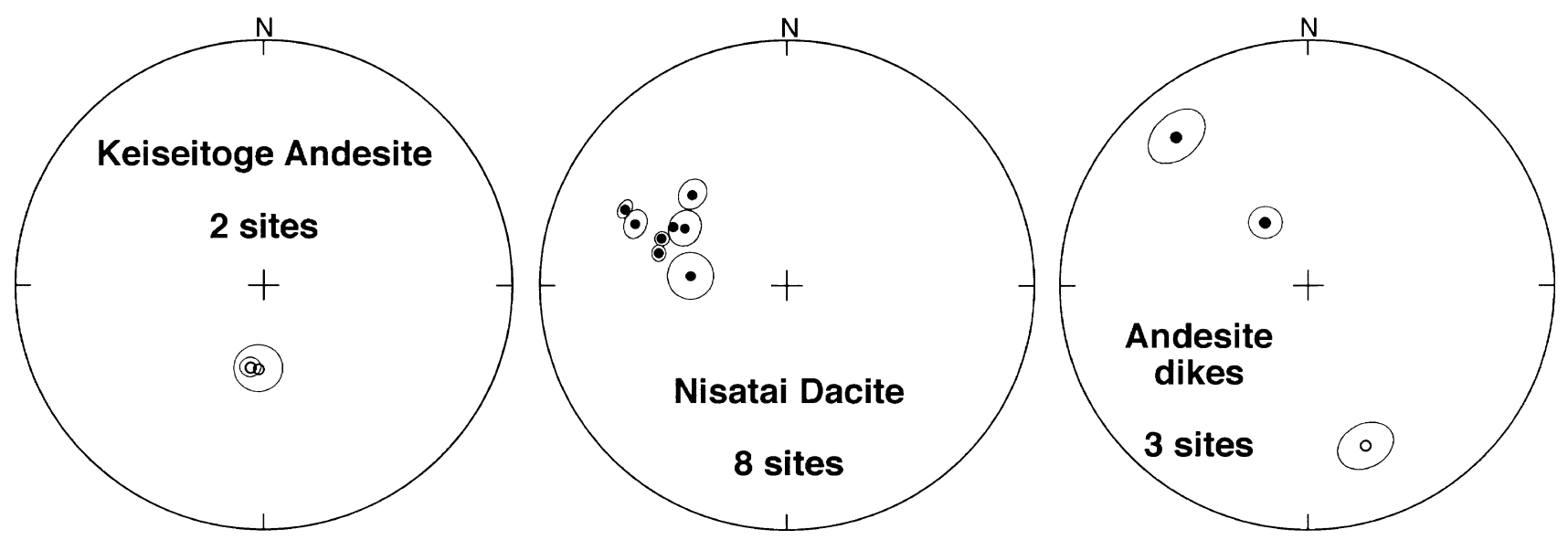

Fig. 4. Site-mean directions with $95 \%$ confidence circles from high-temperature components. The Keiseitoge Andesite and Nisatai Dacite: directions after tilt correction. Andesite dikes: in-situ directions. Equal-area projections with solid circles on the lower hemisphere and open circles on the upper hemisphere.

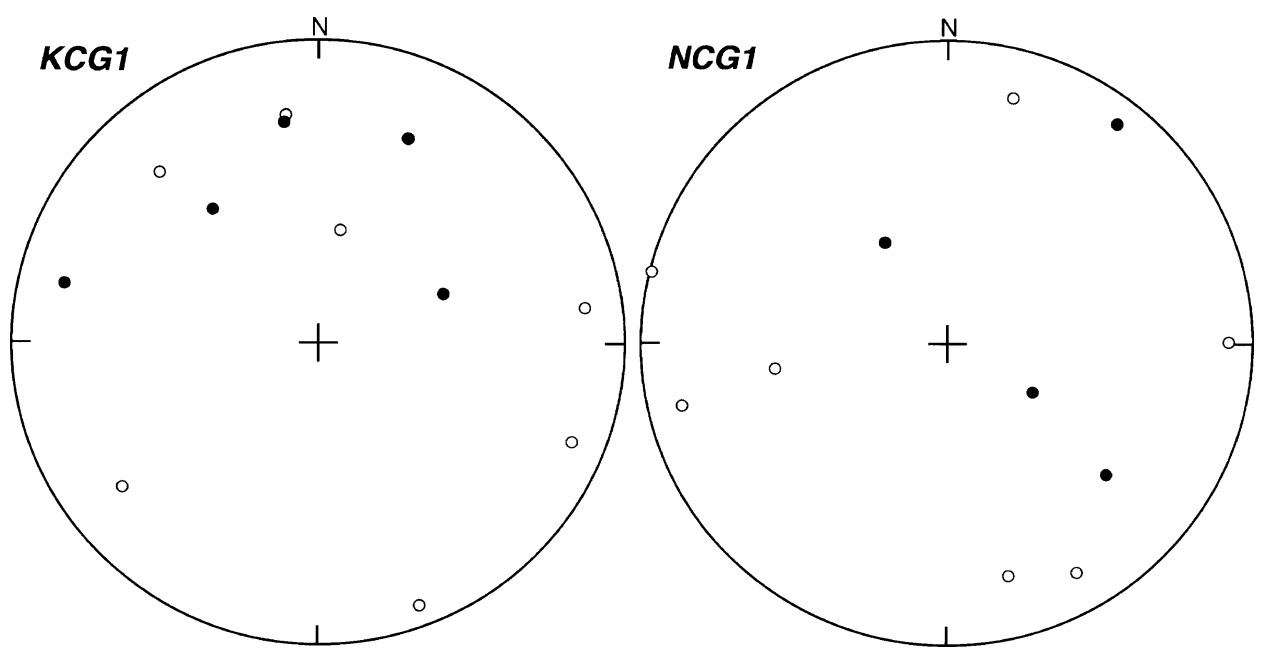

Fig. 5. Equal-area projections of high-temperature component directions after thermal demagnetization for andesite clasts in an interbedded volcaniclastic sequence of the Keiseitoge Andesite (KCG1) and welded tuff clasts in an intraformational conglomerate within the lower part of the Yotsuyaku Formation (NCG1). Open symbols represent the projections on the upper hemisphere, and solid symbols on the lower hemisphere.

acquired during the Brunhes normal polarity chron after tectonic stratal tilting.

\subsection{Conglomerate test}

A conglomerate test (Graham, 1949) was carried out to verity the origin and stability of the HTCs of the Nisatai Dacite and Keiseitoge Andesite. Conglomerate clasts were collected from sites NCG1 and KCG1; the former is in an intraformational conglomerate bed within the lower part of the Yotsuyaku Formation, and the latter is within an interbedded volcaniclastic sequence of the Keiseitoge Andesite. Site NCG1 contains welded tuff clasts derived from the Nisatai Dacite, and almost all clasts within site KCG1 comprise andesite boulders derived from the Keiseitoge Andesite. At each site, twelve clasts were sampled. One specimen was prepared from each sample in the laboratory. PThD was employed for all specimens. Eleven clasts from NCG1 and all the measured clasts from KCG1 provided stable HTCs with randomly distributed directions (Fig. 5); Fisher's (1953) precision parameter $k_{\mathrm{NCG} 1}=1.0$, $k_{\mathrm{KCG} 1}=1.3$. Passage of the conglomerate test confirms that the HTC directions of the Nisatai Dacite and Keiseitoge Andesite are of primary thermoremanent magnetization (TRM) origin.

\section{Amount and Timing of Counter-Clockwise Rotation in the Ninohe Area}

Up to the present, there have been only two site-mean paleomagnetic directions for the Nisatai Dacite (Otofuji et al., 1985, 1994) In this study we have obtained a reliable formation-mean direction from the total of 8 sites. Since each site is at the different stratigraphic position within a sequence of the dacite, the formation-mean can be regarded as representing a time-averaged geomagnetic field direction. The formation-mean direction displayed westward deflection in declination $\left(D=294.5^{\circ}\right)$, indicating large counter-clockwise rotation of the study area since the formation of the dacite ( 21 Ma: Tagami et al. 1995). On the other hand, the Keiseitoge Andesite retains little deflected declinations, demonstrating that the counter-clockwise rotation had ended by $17 \mathrm{Ma}$. 
To quantify the amount of vertical-axis rotation in the study area since $21 \mathrm{Ma}$, we calculated the amount of rotation with respect to the North China Block (NCB: Lin et al., 1985) in the Asian continent. The pole-space method (Beck et al., 1986) was applied, in which vertical-axis rotation of the study area relative to the reference NCB was determined; we made a comparison between the Early to Middle Miocene paleomagnetic pole for the $\mathrm{NCB}\left(85.2^{\circ} \mathrm{N}, 238.4^{\circ} \mathrm{E}\right.$ with $A_{95}$ $=5.6^{\circ}:$ Zhao et al., 1994) and the observed pole $\left(34.7^{\circ} \mathrm{N}\right.$, $58.5^{\circ} \mathrm{E}$ with $A_{95}=8.4^{\circ}$ ) determined from the $21 \mathrm{Ma}$ Nisatai Dacite in the study area located at a representative geographic location $\left(40.3^{\circ} \mathrm{N}, 141.3^{\circ} \mathrm{E}\right)$. Our calculation yields $R$ (rotation estimate) $\pm d R$ (uncertainty: Demarest, 1983) =$72 \pm 10^{\circ} . R$ is defined as negative for counter-clockwise rotation. We therefore conclude that the Ninohe area rotated $72 \pm 10^{\circ}$ counter-clockwise with respect to the NCB between 21 and $17 \mathrm{Ma}$

\section{Paleomagnetic Rotations in NE Japan}

Figure 6(A) shows paleomagnetic declinations with their 95\% confidence limits of 24-21 Ma rock units in northern
NE Japan. Our newly-obtained direction from the Nisatai Dacite is also indicated. Early Early Miocene (24-21 Ma) felsic to intermediate volcanic rocks are sporadically distributed in NE Japan, and a number of paleomagnetic investigations have been carried out on these rocks (Otofuji et al., 1985, 1994; Nishitani and Tanoue, 1987; Tosha and Hamano, 1988; Fujiwara, 1992). The Fukuyama Formation in the Oshima Peninsula and the Daijima Formation in the Oga Peninsula, as well as the Nisatai Dacite in the Ninohe area, are well dated with radiometric methods (Nishimura and Ishida, 1972; Suzuki, 1980; Ganzawa, 1983, 1987; Kimura, 1986; Koshimizu et al., 1986; Tagami et al., 1995). Only one fission-track age of $24.7 \pm 1.2 \mathrm{Ma}$ for the Kunitomi Formation in the Oshima Peninsula, which is part of unpublished data of T. Matsuda, is introduced by Otofuji et al. (1994). No radiometric ages have hitherto been published from the Gongenzaki Formation in the Tsugaru Peninsula; but the lithofacies (mainly andesitic volcanics including welded tuffs and lava flows) resembles closely that of the Fukuyama Formation. We therefore consider the depositional age of the Gongenzaki Formation to be almost identical with that

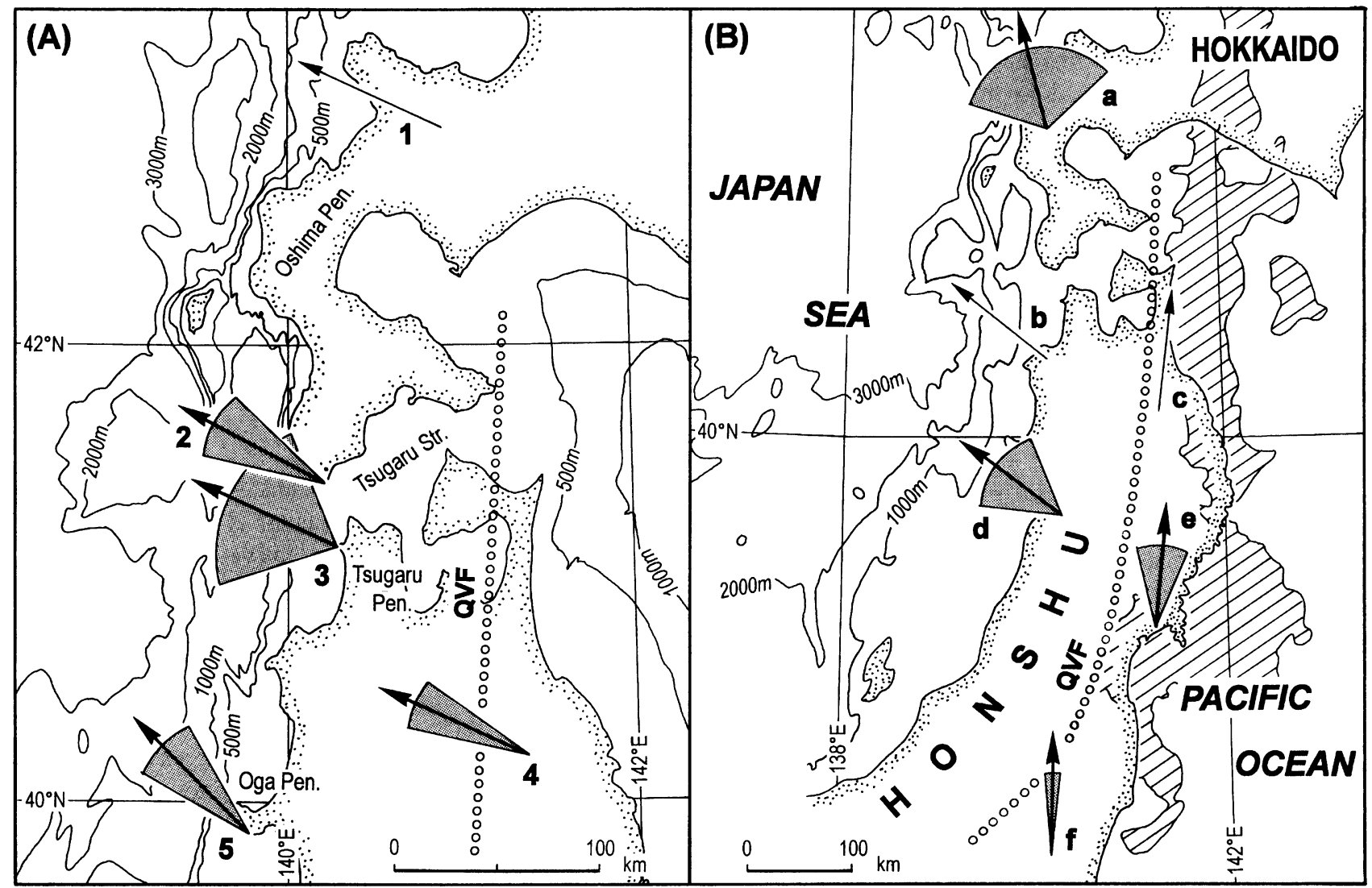

Fig. 6. Directions of paleomagnetic declination of lower Miocene geologic formations in NE Japan. The mean declinations are indicated by arrows along with the $95 \%$ confidence limits $\left(d D=\sin ^{-1}\left[\sin \alpha_{95} / \cos I\right]\right.$, where $\alpha_{95}$ is the radius of the $95 \%$ confidence circle and $I$ is the inclination: Kellogg and Reynolds, 1978). QVF: Quaternary volcanic front. (A) $24-21 \mathrm{Ma}$. 1: Kunitomi Formation in the Oshima Peninsula $\left(D / I=295.8^{\circ} / 64.8^{\circ}, 2\right.$ sites: Otofuji et al., 1994). 2: Fukuyama Formation in the Oshima Peninsula $\left(D / I=298.2^{\circ} / 50.4^{\circ}\right.$ with $\alpha_{95}=10.2^{\circ}, 9$ sites: Fujiwara, 1992 ; Otofuji et al., 1994). 3: Gongenzaki Formation in the Tsugaru Peninsula $\left(D / I=295.1^{\circ} / 55.6^{\circ}\right.$ with $\alpha_{95}=22.7^{\circ}, 3$ sites: Otofuji et al., 1994$)$. 4 : Nisatai Dacite of the Ninohe area $\left(D / I=294.5^{\circ} / 44.2^{\circ}\right.$ with $\alpha_{95}=8.3^{\circ}, 8$ sites: this study $)$. 5: Daijima Formation in the Oga Peninsula $\left(D / I=315.0^{\circ} / 50.8^{\circ}\right.$ with $\alpha_{95}$ $=9.8^{\circ}, 6$ sites: Otofuji et al., 1985; Tosha and Hamano, 1988). (B) $18-16$ Ma. a: Masukawa Formation in the Oshima Peninsula $\left(D / I=346.6^{\circ} / 57.7^{\circ}\right.$ with $\alpha_{95}=27.3^{\circ}, 3$ sites: Otofuji et al., 1994). b: Odose Formation of the Tsugaru area $\left(D / I=308.1^{\circ} / 67.3^{\circ}, 1\right.$ site: Otofuji et al., 1994). c: Keiseitoge Andesite of the Ninohe area $\left(D / I=6.6^{\circ} / 61.9^{\circ}, 2\right.$ sites: this study $)$ d: Yashiozawagawa Formation of the Yashima area $\left(D / I=306.9^{\circ} / 59.0^{\circ}\right.$ with $\alpha_{95}$ $=15.2^{\circ}, 3$ sites: Otofuji et al., 1994). e: Otsuka and Matsushima Formations of the Matsushima Bay area $\left(D / I=5.0^{\circ} / 45.9^{\circ}\right.$ with $\alpha_{95}=12.2^{\circ}, 6$ sites: Yamazaki, 1989). f: Motokozawa Basalt of the Motegi area $\left(D / I=0.3^{\circ} / 48.3^{\circ}\right.$ with $\alpha_{95}=3.4^{\circ}, 25$ sites: Hoshi and Takahashi, 1997$)$. A positive magnetic anomaly belt (Segawa and Oshima, 1975: oblique-line area) is clearly recognized from the Matsushima area to Hokkaido. 
of the Fukuyama Formation (i.e., 24-21 Ma).

It is unambiguously recognized in Fig. 6(A) that individual declinations deflect uniformly counter-clockwise and are parallel or subparallel to each other. The large counter-clockwise deflections are observed in the area east of the Quaternary volcanic front (Sugimura and Uyeda, 1973; Ohguchi et al., 1989) as well as west of it. This remarkable feature led Otofuji et al. (1994) to assert that northern NE Japan, including northern Honshu and southwestern Hokkaido, rotated counter-clockwise after $20 \mathrm{Ma}$ as a "single rigid block." Otofuji et al. (1994) further calculated the amount of rotation by fitting a function on their paleomagnetic data. Finally, they concluded that the rotation occurred at about $15 \mathrm{Ma}$, and that the amount of rotation was $46.4^{\circ}$. As stressed by Jolivet et al. (1995), the uniformity of paleomagnetic directions, however, may also be produced by intra-arc deformation in a strike-slip regime. In a simple block model with a simple geometry (Ron et al., 1984, 1986; McKenzie and Jackson, 1986; Nur et al., 1986), crustal blocks rotate by the same amount and thus it might be impossible to detect a difference in the distribution of paleomagnetic rotations between a single rigid block and several dominoes bounded by parallel or subparallel strikeslip faults. In this context, it is quite important in study of tectonic rotations to examine geologic structures of the given region. Unfortunately, more than half of NE Japan has been masked by thick volcanic and sedimentary sequences which have accumulated up since an early Middle Miocene marine transgression (e.g., Yamaji, 1990). In addition, an intensive contractile stress field since the latest Miocene has complicated the geologic structures, especially in the backarc side (Sato, 1989). Thus it is virtually impossible to delineate the possible intra-arc block rotations in NE Japan through geologic structural approach. Nevertheless, we consider that northern NE Japan was not a single rigid block but a multi-block system in Early Miocene time, the reason being found in the following.

Figure 6(B) shows the paleomagnetic declinations of 18$16 \mathrm{Ma}$ geologic units in NE Japan. All units we selected here, except the Odose Formation of the Tsugaru area, have been well dated with radiometric and magneto-biostratigraphic methods. While the Odose Formation has little information about its depositional age, the fossiliferous marine sediments overlying the formation suggest that the upper limit of the formation is as old as $17 \mathrm{Ma}$ (Hirayama and Uemura, 1985; Suzuki and Nemoto, 1995), and a local correlation of lithostratigraphic units implies that the lower limit is younger than $20 \mathrm{Ma}$ (Fukudome et al., 1990). The fore-arc region of NE Japan is characterized by the dominance of northward declinations. The Motokozawa Basalt in the Motegi area (Hoshi and Takahashi, 1997), dated as about $18 \mathrm{Ma}$, has no deflected declinations. Hoshi and Takahashi (1997) further measured the paleomagnetism of upper formations and clarified that the Motegi area has undergone no tectonic rotation since $18 \mathrm{Ma}$. Yamazaki (1989) also pointed out that no rotational motion has occurred in the Matsushima Bay area since $16 \mathrm{Ma}$. Our result from the Ninohe area demonstrates little rotational motion since $17 \mathrm{Ma}$. These paleomagnetic evidence indicates that the whole of the forearc region has not experienced any significant rotation since at least $17 \mathrm{Ma}$, most likely $18 \mathrm{Ma}$. In opposition to the forearc region, the declinations in the back-arc region deflect significantly westward. Apparently, this fact represents intra-arc deformation with relative block rotations in $\mathrm{NE}$ Japan.

\section{Discussion}

\subsection{Counter-clockwise rotation of northern NE Japan}

Air-borne and ship-borne surveys have revealed features in magnetic intensity anomalies in and around Japan (e.g., Okubo et al., 1994). A north-south, magnetic intensity anomaly belt under the fore-arc region of northern NE Japan (Fig. 6), running from Matsushima to the southern part of Hokkaido (Segawa and Oshima, 1975; Finn, 1994; Okubo et al., 1994) may result from a Cretaceous batholith, 120-70 $\mathrm{km}$ wide and at least 15-10 km thick (Finn, 1994). Because the anomaly is coherent, we interpret that the fore-arc region of northern NE Japan has behaved as a single block since the Cretaceous (Hoshi and Takahashi, 1997).

Our paleomagnetic results from the Ninohe area suggest that the fore-arc region of northern NE Japan has experienced counter-clockwise rotation sometime between 21 and 17 Ma. The 24-21 Ma Nisatai Dacite yielded a time-averaged, formation-mean paleomagnetic direction deflecting markedly $\left(>60^{\circ}\right)$ counter-clockwise. Although in the fore-arc region this is the only result showing counter-clockwise deflection in declination, we consider, on the basis of the above implication from magnetic intensity anomalies, that the region ranging from at least Matsushima to southern Hokkaido uniformly rotated counter-clockwise through more than $60^{\circ}$ after $21 \mathrm{Ma}$. Since we have seen in a previous section that the whole of the fore-arc side of NE Japan has not undergone rotational motion since $17 \mathrm{Ma}$, we conclude that the region rotated counter-clockwise through more than $60^{\circ}$ in the period between 21 and $17 \mathrm{Ma}$. In other words, northern NE Japan must have rotated by the same amount at that time.

Our conclusion seems to be consistent with some statistical estimates of the amount of counter-clockwise rotation of NE Japan (Otofuji et al., 1994; Jolivet et al., 1995), but apparently discordant with that of Tosha and Hamano (1988). Tosha and Hamano estimated the amount of rotation at only about $20^{\circ}$. This value was obtained by comparing a Cenozoic apparent polar wander path (APWP) for the Oga Peninsula with that for the Kilchu-Myongchon Graben in North Korea (Kang, 1966; Sasajima, 1981). The ages of the APWP for the Kilchu-Myongchon Graben, however, have been not determined precisely, as stated in the Tosha and Hamano's own paper. In addition, paleomagnetic directions of Eocene to Miocene geologic formations of the Kilchu-Myongchon Graben seem to be somewhat questionable; these deflect counter-clockwise about $20^{\circ}$ (therefore the rotation of NE Japan was estimated rather small). Such a westerly deflection is inconsistent with the recent paleomagnetic data from the nearby North and South China Blocks (Zhao et al., 1990, 1994; Zheng et al., 1991). We think the depositional age and regional geology should be reassessed for the paleomagnetic sites in the Kilchu-Myongchon Graben in North Korea. The Early Miocene counter-clockwise rotation of northern NE Japan must have reached more than $60^{\circ}$. 
Northern NE Japan is considered to have rotated before 17 Ma, whereas SW Japan rapidly rotated clockwise at about 15 Ma (Hayashida, 1986; Nakajima et al., 1990; Otofuji et al., 1991). This suggests diachronic differential rotation in the Japan Arc in the opening period of the Japan Sea. Otofuji et al. $(1985,1994)$ urged that the Japan Sea opened in a "bardoor" fashion with almost concurrent differential rotations of two arcs (NE and SW Japan) at about $15 \mathrm{Ma}$. However, recent Ocean Drilling Program(ODP) and marine geological/ geophysical results from the Japan Sea (Kaneoka et al., 1990, 1992; Burckle et al., 1992; Nomura, 1992; Pouclet and Bellon, 1992; Rahman, 1992; Tamaki et al., 1992) have revealed that the basins underlain by oceanic or highly stretched continental crust have existed before $15 \mathrm{Ma}$, partly at about $20 \mathrm{Ma}$. Our assertion that northern NE Japan rotated before 17 Ma seems to be concordant with the offshore data. Hayashida et al. (1991) proposed an interesting kinematic model for SW Japan; it has been translated southward without detectable rotation before $16 \mathrm{Ma}$ and then rotated clockwise. It is hence highly probable that the counterclockwise rotation of northern NE Japan and the possible southward translation of SW Japan were contemporaneous with each other.

\subsection{Intra-arc block rotations in NE Japan}

Paleomagnetic rotations have been observed in Middle Miocene formations as well as Early Miocene ones in the back-arc region of NE Japan, suggesting block rotations in the region during and after the counter-clockwise arc rotation. The Gongenyama Formation in the Japan Sea coastal area, dated as 14-15 Ma through biostratigraphic correlations, shows a slight counter-clockwise deflection in declination (Momose et al., 1990), implying a small rotation since then. A Middle Miocene counter-clockwise deflection was also reported from the Masukawa Formation in the Oshima Peninsula (Otofuji et al., 1994: Fig. 6). Thus it is most likely that intra-arc deformation with relative rotations occurred at various scales in several areas of the back-arc region during and after the Early Miocene arc rotation. Otofuji et al. (1994) concluded, on the basis of their own paleomagnetic data mainly sampled from the back-arc region, that NE Japan rotated counter-clockwise at about $15 \mathrm{Ma}$. We think some Middle Miocene paleomagnetic directions influenced by local block rotations led them to conclude so.

Jolivet et al. (1995) try to reconcile observed paleomagnetic rotations in the Japan Arc with a geologically supposed dextral strike-slip environment in a single kinematic model. Their model interprets that NNE-SSW trending major dextral strike-slip faults guided the opening of the Japan Sea in a pull-apart manner. This model appears to account partly for the local block rotations in the Japan Sea coastal area of NE Japan, while the model in turn cannot account for the amount of the counter-clockwise arc rotation. Further paleomagnetic, chronological and geological studies and tectonic consideration are required to thoroughly describe the geodynamic history of the Japan Arc.

Acknowledgments. We would like to thank Toshitsugu Yamazaki, Masaki Takahashi and two anonymous reviewers for valuable suggestions on the earlier version of the manuscript. Pieces of technical advice from Hiroyuki Nagahama are also appreciated.
This research was partly supported by the Fukada Geological Institute Foundation.

\section{References}

Barron, J. A. and A. Y. Gladenkov, Early Miocene to Pleistocene diatom stratigraphy of Leg 145, in Proceedings of the Ocean Drilling Program, Scientific Result, Vol. 145, edited by D. K. Rea, I. A. Basov, D. W. Scholl, and J. F. Allan, pp. 3-19, Ocean Drilling Program, College Station, TX, 1995.

Beck, M. E., Jr., R. F. Bumester, D. E. Craig, C. S. Gromme, and R. E. Wells, Paleomagnetism of middle Tertiary volcanic rocks from the Western Cascade Series, Northern California, J. Geophys. Res., 91, 8219-8230, 1986.

Berggren, W. A., D. V. Kent, C. C. Swisher, III, and M. P. Aubry, A revised Cenozoic geochronology and chronostratigraphy, in Geochronology, Time Scales and Stratigraphic Correlation, edited by W. A. Berggren, D. V. Kent, M. P. Aubry, and J. Hardenbol, pp. 129-212, Society of Sedimentary Geology Special Publication No. 54, SEPM, Tulsa, 1995.

Blow, W. H., Late Middle Eocene to recent planktonic foraminiferal biostratigraphy, in Proceedings of the First International Conference on Planktonic Microfossils, Geneva 1969, Vol. 1, edited by P. Bronnimann and H. H. Renz, pp. 199-422, E. J. Brill, Leiden, 1969.

Burckle, L. H., C. A. Brunner, J. Alexandrovich, P. DeMenocal, J. Briscoe, Y. Hamano, L. Heusser, J. C. Ingle, Jr., I. Kheradyar, I. Koizumi, K. A. O. Krumsiek, H. Y. Ling, J. P. Muza, A. Rahman, A. Stult, L. Vigliotti, L. D. White, J. J. M. Wippern, and T. Yamanoi, Biostratigraphic and biochronological synthesis of Legs 127 and 128: Sea of Japan, in Proceedings of the Ocean Drilling Program, Scientific Result, Vol. 127/128, Part 2, edited by K. Tamaki, K. Suyehiro, J. Allan, M. McWilliams et al., pp. 1219-1228, Ocean Drilling Program, College Station, TX, 1992.

Cande, S. C. and D. V. Kent, Revised calibration of the geomagnetic polarity time scale for the Late Cretaceous and Cenozoic, J. Geophys. Res., 100, 6093-6095, 1995

Celaya, M. and R. McCabe, Kinematic model for the opening of the Sea of Japan and the bending of the Japanese islands, Geology, 15, 53-57, 1987.

Demarest, H. H., Jr., Error analysis for the determination of tectonic rotation from paleomagnetic data, J. Geophys. Res., 88, 4321-4328, 1983.

Finn, C., Aeromagnetic evidence for a buried Early Cretaceous magmatic arc, northeast Japan, J. Geophys. Res., 99, 22165-22185, 1994.

Fisher, R., Dispersion on a sphere, Proc. R. Soc. London, Ser. A, 217, 295305, 1953.

Fujiwara, Y., Paleomagnetic studies of the Tertiary rocks in southwestern Hokkaido, Northeast Japan, J. Fac. Sci., Hokkaido Univ., Ser. IV, 23, 159-166, 1992.

Fukudome, T., T. Yoshida, K. Nagao, T. Itaya, and S. Tanoue, Pliocene alkali basalt from Kyuroku-shima Island, northeast of Japan Sea, J. Min. Petr. Econ. Geol., 85, 10-18, 1990 (in Japanese with English abstract).

Ganzawa, Y., "Green Tuff" movement defined by fission track ages of igneous rocks: Part 2 Futomiyama area of Toyama Prefecture, central Japan, J. Geol. Soc. Japan, 89, 271-286, 1983 (in Japanese with English abstract).

Ganzawa, Y., Fission track ages of volcanic rocks from Cretaceous to Tertiary in the inner belt of Northeast Japan: Okushiri Island, Oga Peninsula and Asahi Mountains, J. Geol. Soc. Japan, 93, 387-401, 1987 (in Japanese with English abstract).

Graham, J. W., The stability and significance of magnetism in sedimentary rocks, J. Geophys. Res., 54, 131-167, 1949.

Hayashida, A., Timing of rotational motion of Southwest Japan inferred from paleomagnetism of the Setouchi Miocene Series, J. Geomag. Geoelectr., 38, 295-310, 1986.

Hayashida, A., Paleomagnetic directions of the Kadonosawa area and the rotation of Northeast Japan, Chikyu Monthly, 16, 135-138, 1994 (in Japanese).

Hayashida, A., T. Fukui, and M. Torii, Paleomagnetism of the Early Miocene Kani Group in Southwest Japan and its implication for the opening of the Japan Sea, Geophys. Res. Lett., 18, 1095-1098. 1991. Hirayama, J. and F. Uemura, Geology of the Ajigasawa District, with 
geological sheet map at 1:50000, 86 pp., Geol. Surv. Japan, 1985 (in Japanese with English abstract).

Hoshi, H. and M. Takahashi, Paleomagnetic constraints on the extent of tectonic blocks and the location of their kinematic boundaries: Implications for Miocene intra-arc deformation in Northeast Japan, J. Geol. Soc. Japan, 103, 523-542, 1997.

Hoshi, H., M. Takahashi, and K. Saito, Paleomagnetic study of the Miocene Yoshino Formation, Yamagata Prefecture, Rock. Mag Paleogeophys., 19, 38-42, 1992.

Irizuki, T. and T. Matsubara, Vertical changes of depositional environments of the Lower to Middle Miocene Kadonosawa Formation based on analyses of fossil ostracode faunas, J. Geol. Soc. Japan, 100, 136149, 1994 (in Japanese with English abstract).

Ishizuka, O. and K. Uto, K-Ar ages of Neogene volcanic rocks in the Ninohe area, Programme and Abstracts, Volcanological Society of Japan, No. 2, p. 4, 1995 (in Japanese).

Jolivet, L., H. Shibuya, and M. Fournier, Paleomagnetic rotations and the Japan Sea opening, in Active Margins and Marginal Basins of the Western Pacific, Geophysical Monograph 88, edited by B. Taylor and J. Natland, pp. 355-369, American Geophysical Union, Washington, D.C., 1995

Kaneoka, I., K. Notsu, Y. Takigami, K. Fujioka, and H. Sakai, Constraints on the evolution of the Japan Sea based on ${ }^{40} \mathrm{Ar}-{ }^{39} \mathrm{Ar}$ ages and $\mathrm{Sr}$ isotopic ratios for volcanic rocks of the Yamato Seamount Chain in the Japan Sea, Earth Planet. Sci. Lett., 97, 211-225, 1990.

Kaneoka, I., Y. Takigami, N. Takaoka, S. Yamashita, and K. Tamaki, ${ }^{40} \mathrm{Ar}-{ }^{39} \mathrm{Ar}$ analysis of volcanic rocks recovered from the Japan Sea floor: Constraints on the age of formation of the Japan Sea, in Proceedings of the Ocean Drilling Program, Scientific Result, Vol. 127/ 128, Part 2, edited by K. Tamaki, K. Suyehiro, J. Allan, M. McWilliams et al., pp. 819-836, Ocean Drilling Program, College Station, TX, 1992.

Kang, Y. H., A paleomagnetic study on the Cretaceous and Mesozoic rocks of north Korea, Geol. Geogr, 7, 4-9, 1966 (in Korean).

Kellogg, K. S. and R. L. Reynolds, Paleomagnetic results from the Lassiter Coast, Antarctica, and a test for oroclinal bending of the Antarctic Peninsula, J. Geophys. Res., 83, 2293-2299, 1978.

Kimura, K., Chronostratigraphic classification of the Lower and Middle Tertiary formations in the Oga, Akita and Honjo-Yuzawa areas: a study based on stratigraphic relations and radiometric ages, in Essays in Geology: Professor Nobu Kitamura Commemorative Volume, edited by H. Nakagawa, T. Kotaka, and Y. Takayanagi, pp. 167-173, Professor Nobu Kitamura Taikan Kinenjigyo-kai, Sendai, 1986 (in Japanese with English abstract).

Kirschvink, J. L., The least squares line and plane and the analysis of palaeomagnetic data, Geophys. J. R. Astr. Soc., 62, 699-718, 1980.

Koizumi, I., Miocene siliceous deposits and oceanic events, Marine Science Monthly, 189, 146-153, 1986 (in Japanese).

Koshimizu, S., J. Yamazaki, and M. Kato, Fission-track dating of the Cainozoic formations in the Oshima Peninsula, southwestern Hokkaido, Japan, J. Geol. Soc. Japan, 92, 771-780, 1986 (in Japanese with English abstract).

Lin, J., M. Fuller, and W. Zhang, Preliminary Phanerozoic polar wander paths for the North and South China blocks, Nature, 313, 444-449, 1985.

Matsubara, T., Fossil Mollusca of the Lower Miocene Yotsuyaku Formation in the Ninohe district, Iwate Prefecture, Northeast Japan: Part 1. General consideration of the fauna, Trans. Proc. Palaeont. Soc. Japan, N.S., 180, 303-320, 1995.

McKenzie, D. and J. Jackson, A block model of distributed deformation by faulting, J. Geol. Soc. London, 143, 349-353, 1986

Momose, H., M. Torii, and H. Tanaka, Counter-clockwise paleomagnetic direction from the Gongenyama Formation (N9-N10) on the coastal area of Northeast Japan, Rock Mag. Paleogeophys., 17, 47-50, 1990.

Moreau, M. G., V. Courtillot, and J. Besse, On the possibility of a widespread remagnetization of pre-Oligocene rocks from Northeast Japan and the Miocene rotational opening of the Japan Sea, Earth Planet. Sci. Lett., 84, 321-338, 1987.

Nakajima, T., Y. Sawada, T. Nakagawa, A. Hayashi, and T. Itaya, Paleomagnetic results and $\mathrm{K}$-Ar dating on Miocene rocks in the northern part of Fukui Prefecture, central Japan: With reference to the rotation of Southwest Japan, J. Min. Petr. Econ. Geol., 85, 45-59, 1990 (in Japanese with English abstract).
Nishimura, S. and S. Ishida, Fission-track ages of tuffs of the Neogen Tertiary on Oga Peninsula, Akita Prefecture, Japan, J. Min. Petl. Econ. Geol., 67, 166-168, 1972 (in Japanese with English abstract).

Nishitani, T. and S. Tanoue, Paleomagnetic investigation for the Oga Peninsula in Northeast Japan, Rock Mag. Paleogeophys., 14, 46-51, 1987.

Nomura, R., Miocene benthic foraminifers at Sites 794, 795, and 797 in the Sea of Japan with reference to the Foram Sharp Line in the Honshu arc, in Proceedings of the Ocean Drilling Program, Scientific Result, Vol. 127/128, Part 1, edited by K. A. Pisciotto, J. C. Ingle, Jr., M. T. von Breymann, J. Barron et al., pp. 493-540, Ocean Drilling Program, College Station, TX, 1992

Nur, A., H. Ron, and O. Scotti, Fault mechanics and the kinematics of block rotations, Geology, 14, 746-749, 1986.

Ohguchi, T., T. Yoshida, and K. Okami, Historical change of the Neogene and Quaternary volcanic field in the Northeast Honshu Arc, Japan, Mem. Geol. Soc. Japan, 32, 431-455, 1989 (in Japanese with English abstract).

Okubo, Y., M. Makino, S. Kasuga, N. Isezaki, T. Yamazaki, T. Ishihara, and T. Nakatsuka, Magnetic anomalies of Japan and adjoining areas, $J$. Geomag. Geoelectr., 46, 411-421, 1994.

Otofuji, Y., Large tectonic movement of the Japan Arc in late Cenozoic times inferred from paleomagnetism: Review and synthesis, The Island Arc, 5, 229-249, 1996.

Otofuji, Y., T. Matsuda, and S. Nohda, Paleomagnetic evidence for the Miocene counter-clockwise rotation of Northeast Japan: rifting process of the Japan Arc, Earth Planet. Sci. Lett., 75, 265-277, 1985.

Otofuji, Y., T. Itaya, and T. Matsuda, Rapid rotation of southwest Japan: palaeomagnetism and K-Ar ages of Miocene volcanic rocks of southwest Japan, Geophys. J. Int., 105, 397-405, 1991.

Otofuji, Y., A. Kambala, T. Matsuda, and S. Nohda, Counterclockwise rotation of Northeast Japan: Paleomagnetic evidence for regional extent and timing of rotation, Earth Planet. Sci. Lett., 121, 503-518, 1994.

Pouclet, A. and H. Bellon, Geochemistry and isotopic composition of volcanic rocks from the Yamato Basin: Hole 794D, Sea of Japan, in Proceedings of the Ocean Drilling Program, Scientific Result, Vol. 127/128, Part 2, edited by K. Tamaki, K. Suyehiro, J. Allan, M. McWilliams et al., pp. 779-789, Ocean Drilling Program, College Station, TX, 1992.

Rahman, A., Calcareous nannofossil biostratigraphy of Leg 127 in the Japan Sea, in Proceedings of the Ocean Drilling Program, Scientific Result, Vol. 127/128, Part 1, edited by K. A. Pisciotto, J. C. Ingle, Jr., M. T. von Breymann, J. Barron et al., pp. 171-186, Ocean Drilling Program, College Station, TX, 1992.

Ron, H., R. Freund, Z. Garfunkel, and A. Nur, Block rotation by strikeslip faulting: structural and paleomagnetic evidence, J. Geophys. Res., 89, 6256-6270, 1984.

Ron, H., A. Aydin, and A. Nur, Strike-slip faulting and block rotation in the Lake Mead fault system, Geology, 14, 1020-1023, 1986.

Samata, T., Tertiary planktonic foraminiferal biostratigraphy in the Mabechi River region, northern end of the Kitakami Massif, Northeast Honshu, J. Geol. Soc. Japan, 82, 783-793, 1976 (in Japanese with English abstract).

Sasajima, S., Pre-Neogene paleomagnetism of Japanese islands (and vicinities), in Paleoreconstruction of the Continents, edited by M. W. McElhinny and D. A. Valencio, pp. 115-128, Geodynamic Series, Vol. 2, American Geophysical Union, Washington, D.C., 1981.

Sato, H., Degree of deformation of late Cenozoic strata in the Northeast Honshu Arc, Mem. Geol. Soc. Japan, 32, 257-268, 1989 (in Japanese with English abstract).

Segawa, J. and S. Oshima, Buried Mesozoic volcanic-plutonic fronts of the north-western Pacific island arcs and their tectonic implications, Nature, 256, 15-19, 1975.

Sugimura, A. and S. Uyeda, Island Arc: Japan and Its Environs, 247 pp., Elsevier, Amsterdam, 1973.

Suzuki, M. and N. Nemoto, Miocene foraminifera in the west coast of Aomori Prefecture, Northeast Japan, Rep. Fukaura Mar. Biol. Lab. Hirosaki Univ., 15, 5-21, 1995 (in Japanese with English abstract).

Suzuki, T., Fission track ages of the Tertiary volcanic rocks in the Oga Peninsula, northern Japan, J. Geol. Soc Japan, 86, 441-453, 1980 (in Japanese with English abstract). 
Tagami, T., K. Uto, T. Matsuda, N. Hasebe, and A. Matsumoto, K-Ar biotite and fission-track zircon ages of the Nisatai Dacite, Iwate Prefecture, Japan: A candidate for tertiary age standard, Geochem. J., 29, 207-211, 1995.

Tamaki, K., K. Suyehiro, J. Allan, J. C. Ingle, Jr., and K. A. Pisciotto, Tectonic synthesis and implications of Japan Sea ODP drilling, in Proceedings of the Ocean Drilling Program, Scientific Result, Vol. 127/128, Part 2, edited by K. Tamaki, K. Suyehiro, J. Allan, M McWilliams et al., pp. 1333-1348, Ocean Drilling Program, College Station, TX, 1992.

Tanaka, H., H. Tsunakawa, H. Yamagishi, and G. Kimura, Paleomagnetism of the Shakotan Peninsula, West Hokkaido, Japan, J. Geomag. Geoelectr, 43, 277-294, 1991.

Tosha, T. and Y. Hamano, Paleomagnetism of Tertiary rocks from the Oga Peninsula and the rotation of Northeast Japan, Tectonics, 7, 653662, 1988.

Yamaji, A., Rapid intra-arc rifting in Miocene Northeast Japan, Tectonics, 9, 365-378, 1990

Yamazaki, T., Paleomagnetism of Miocene sedimentary rocks around Matsushima Bay, Northeast Japan and its implication for the time of the rotation of Northeast Japan, J. Geomag. Geoelectr, 41, 533-548, 1989

Zhao, X., R. S. Coe, Y. Zhou, H. Wu, and J. Wang, New paleomagnetic results from northern China: collision and suturing with Siberia and Kazakhstan, Tectonophysics, 181, 43-81, 1990.

Zhao, X., R. Coe, Y. Zhou, S. Hu, H. Wu, G. Kuang, Z. Dong, and J. Wang, Tertiary paleomagnetism of North and South China and a reappraisal of late Mesozoic paleomagnetic data from Eurasia: Implications for the Cenozoic tectonic history of Asia, Tectonophysics, 235, 181-203, 1994.

Zheng, Z., M. Kono, H. Tsunakawa, G. Kimura, Q. Wei, X. Zhu, and T. Hao, The apparent polar wander path for the North China Block since the Jurassic, Geophys. J. Int., 104, 29-40, 1991.

Zijderveld, J. D. A., A.C. demagnetization of rocks: Analysis of results, in Method in Palaeomagnetism, edited by D. W. Collinson, K. M. Creer, and S. K. Runcorn, pp. 254-286, Elsevier, Amsterdam, 1967.

H. Hoshi (e-mail: hoshi@auecc.aichi-edu.ac.jp) and T. Matsubara (e-mail: matsu@nat-museum.sanda.hyogo.jp) 